\title{
The Government as Reinsurer of Catastrophe Risks?
}

\author{
Véronique Bruggeman ${ }^{\mathrm{a}}$, Michael G. Faure ${ }^{\mathrm{a}, \mathrm{b}}$ and Karine Fiore ${ }^{\mathrm{c}}$ \\ ${ }^{a}$ Maastricht European Institute for Transnational Legal Research (METRO), Maastricht University, \\ Bouillonstraat 3, Maastricht 6211LH, the Netherlands. \\ E-mail: michael.faure@maastrichtuniversity.nl \\ ${ }^{\mathrm{b}}$ Rotterdam Institute of Law and Economics, Erasmus University Rotterdam, Brugemeester Oudlaan 50, \\ PO Box 17383000 DR Ritterdam, the Netherlands. \\ ${ }^{\mathrm{c} C e n t r e ~ d ' A n a l y s e ~ E c o n o m i q u e, ~ U P C A M, ~ 3, ~ a v e ~ R o b e r t ~ S c h u m a n, ~} 13628$ Aix-en-Provence cedex1, France. \\ E-mail: karinefiore@yahoo.fr
}

Compensation for victims of catastrophes is a hot topic in many countries today. Consequently, the legislator is increasingly intervening in the catastrophe insurance market in order to stimulate its functioning. Various forms of public-private partnerships have hence developed, although law and economics scholarship has differing views on this type of government intervention. The aim of this paper is to add to that debate by, on the one hand, discussing a few specific cases where the government acts as a reinsurer of last resort or as a primary insurer, and by, on the other hand, confronting these practical examples with five main conditions that would have to be fulfilled to make government intervention efficient-or at least as little disruptive as possible: market failure, the charging of risk-based premiums, the stimulation of existing market solutions, the freedom to choose for State reinsurance and the temporary character.

The Geneva Papers (2010) 35, 369-390. doi:10.1057/gpp.2010.10

Keywords: state; reinsurance; catastrophe risks; compensation; public-private partnership

\section{Introduction}

Catastrophes have always happened but they increasingly reveal new dimensions to the nature of the risks populations are subjected to and the magnitude of their consequences. Technological, industrial, natural and terrorist risks have become the result of the diversification of human and economic activities. Further, these multiple risks might entail serious consequences, such as large, cross-border and irreversible damages. Facing these new dimensions of risk, governments progressively intervene in the field of financial compensation for victims of catastrophes. This choice has been mainly justified to protect the victims, for two reasons. On the one hand, catastrophes are often the consequence of unilateral accidents to which victims do not contribute at all. That is the case, for example, of nuclear or chemical accidents which are the result of an industrial activity, the risk of which cannot be influenced by victims' behaviour. Therefore, victims should have the guarantee they will obtain compensation in case of an accident. This is all the more important since victims might not be insured for such particular risks. On the other hand, governments often intervene in compensation for victims of catastrophes in order to remedy the injurer's (and even the insurers') potential insolvency, since damages might be very large and costly. As a consequence, State intervention (instead or additionally to injurers/insurers) is a way of guaranteeing that compensation is fully paid. 
The way government intervention in compensation for victims of catastrophes is organised varies from one country to another and from one sector to another. Governments intervene either because there does not exist any other (satisfying) solution in the private market or to complete existing compensation schemes. However, although government intervention in compensation contributes to the protection of catastrophe victims, it also shows limits and problems - as has already been discussed in law and economics literature.

Hence, on the one side, government intervention in compensation for victims of catastrophes may be desirable. On the other side, it appears to be inefficient as well. The central goal of our paper is therefore to examine whether it would be possible to organise this government intervention in a more cost-effective manner (at lower costs and with a reduced subsidising character). Our examination hereby relies on examples of existing compensation schemes and insurance for terrorist, natural (flooding in particular) and industrial catastrophes.

The government could act as reinsurer of last resort; in that case, the government adds an additional risk layer and in fact works together with the private insurance market, which is not able to fully compensate the catastrophe victims. The government could also act as primary insurer in cases where it is held that the market does not offer any catastrophe insurance at all. Most of the cases that we will focus upon in this paper concern the role of the government as reinsurer, although there is one case (being the California Earthquake Authority (CEA), to be discussed in section "The California Earthquake Authority - the government as a primary insurer") where the government acts as primary insurer. We have added this case to show that the government acting as primary insurer is far more problematic than the case where the government merely intervenes as reinsurer of last resort, the main focus of our paper.

Given this purpose, our paper is structured as follows: after an introduction we briefly show how the traditional law and economics literature views government intervention with respect to catastrophe risks. We then ask the question under what type of conditions government intervention may be acceptable, whereby we focus on the case of reinsurance by the government. We compare these conditions to a few current evolutions where governments act as traditional reinsurers and actually claim a price for their intervention. We then formulate a few conclusions at the policy level, inter alia addressing under which conditions government intervention could be second best.

\section{A law and economics perspective}

\section{Focus on compensation}

The role of the government with respect to catastrophes - be it man-made or natural disasters - can take a lot of shapes and forms. ${ }^{1}$ Governments can obviously ex ante take many measures in the prevention of disasters, but also on an ex post level, they can provide immediate disaster relief and assistance to victims. We only focus on the role of the government in providing compensation to victims of catastrophes. Even

\footnotetext{
${ }^{1}$ For an overview see inter alia Sugarman (2007).
} 
there, the roles that the government could theoretically fulfil can vary quite a bit. We will briefly discuss mandatory comprehensive disaster insurance and ex post relief provided by the government either ad hoc or through a compensation fund. The strengths (and weaknesses) of the former have been discussed at length in the law and economics literature, ${ }^{2}$ while ex post relief has been qualified by many law and economics scholars as problematic. As the title of our paper suggests, we will mainly focus on the potential role for the government in reinsuring catastrophe risks. It is this role of the government as reinsurer of last resort that gains increasing attention in law and economics literature, arguing that the government could support failing insurance markets.

\section{Mandatory comprehensive insurance}

Empirical evidence has demonstrated that even in those countries where disaster insurance is widely available, individuals tend not to make sufficient use of it, resulting in dramatic cases of underinsurance. This was shown for example after the "flood of the century" of the river Elbe in Germany $^{3}$ as well as in the U.S. especially after Katrina. ${ }^{4}$ Several reasons are indicated for this low demand for disaster insurance. First, as a result of cognitive limitations, low probability events like natural disasters are systematically misjudged ${ }^{5}$ resulting in a "it will not happen to me" attitude. ${ }^{6}$ Second, there is equally empirical evidence that people ex ante prefer uncertain losses rather than the certain loss incurred by paying the insurance premium. Insurance is considered as an investment and potential victims (such as house owners) have a low expectation of a return on this investment during a lifetime and hence a low demand. ${ }^{7}$ Third, some literature, to which we will come back below, indicates that also ex post government relief provided after a disaster reduces incentives to purchase insurance coverage. ${ }^{8}$

For these and other reasons, many scholars and especially Kunreuther have argued in favour of compulsory (first-party) insurance for property damage caused by natural disasters. ${ }^{9}$ An example of such a mandatory comprehensive disaster insurance constitutes the case of France. In that country, homeowners who purchase voluntary housing insurances are, as a result of a regulatory duty, automatically insured against damage caused by natural disasters. ${ }^{10}$ This model whereby the duty to insure against disasters is combined with an insurance against a high-probability low-damage event is also supported by behavioural literature: individuals would prefer disaster insurance

\footnotetext{
${ }^{2}$ And has also been the subject of a recent paper by us. See Faure and Bruggeman (2009).

${ }^{3}$ See for example Endres et al. (2003); Magnus (2006); and Schwarze and Wagner (2004).

${ }^{4}$ See Daniels et al. (2006).

${ }^{5}$ See Slovic et al. (2000).

${ }^{6}$ Kunreuther (1996, p. 175).

${ }^{7}$ Slovic et al. (1977).

${ }^{8}$ This is a point strongly made by Epstein (1996) and by Harrington (2000).

${ }^{9}$ It is an argument already made by Kunreuther (1968) and repeated regularly, inter alia after Katrina (Kunreuther and Pauly (2006)).

${ }^{10}$ See Moréteau et al. (2006) and Moréteau (2007).
} 
when it is combined with an insurance against high-probability low-damage losses. ${ }^{11}$ Thus it is argued that compulsory comprehensive insurance plays an important role in improving hazard perception. ${ }^{12}$

Even though such a compulsory comprehensive insurance does not go totally undisputed (especially in those cases where it would also force individuals who run no risk at all ${ }^{13}$ to take insurance coverage as well) there seems to be support for such a regulatory policy in law and economics scholarship. ${ }^{14}$ However, even if the lacking demand for disaster insurance would have been solved by making the insurance purchase compulsory, problems can also arise on the supply side, more particularly given the "difficult to predict" nature of catastrophes. ${ }^{15}$ Hence, the question still arises what role there could be for the government in case the amount of the damage caused by the disaster is higher than normal insurance policies would be able to cover. One possibility is to provide outright government relief; another is to combine insurance with government support.

\section{Ex post relief}

One possibility for the government to stimulate compensation for victims of catastrophes is to simply take over the compensation function and provide ex post relief to victims. This type of ex post relief could take different forms. There could, for example, be a disaster compensation fund ${ }^{16}$ or there could simply be ad hoc compensation whereby the government decides on the basis of the nature and scope of the disaster how much of what particular type of relief to provide. It would go too far to discuss all these varieties here in detail.

Generally, these forms of ex post relief provide lump sum payments to victims and are financed by the general tax payers. However, they are often criticised in law and economics scholarship: ${ }^{17}$

- A first major disadvantage of the lump sum payment under government relief is that no incentives are provided to potential victims to take effective preventive measures. In that respect, the literature argues that competitive insurance markets are better able to deal with moral hazard and adverse selection via risk differentiation. ${ }^{18}$

${ }^{11}$ See Slovic (2000, pp. 60-61 and 70-71).

12 Slovic et al. (2000, p. 25).

${ }^{13}$ Like the person living in an apartment on the $10^{\text {th }}$ floor who barely has any risk of being flooded.

${ }^{14}$ Mandatory disaster insurance is not the central focus of this paper. For more details see Faure and Bruggeman (2009). See also Levmore and Logue (2003, p. 304).

${ }^{15}$ For a more detailed analysis of problems on the supply side, see Gollier (2005) and the contributions in Froot (1999).

${ }^{16}$ Which is, for example, the case in Austria (see Hinghofer-Szalkay and Koch, 2006) and in Belgium (see Durant, 2006).

${ }^{17}$ Obviously, the criticisms partially depend upon the nature of the arrangement. To the extent that government relief can be structured in such a way that some incentives can still be provided to victims (e.g. by including deductibles or by differentiating the amount of compensation taking into account preventive measures taken) and that the financing can to some extent still be risk-based (although that is seldom the case) the criticisms may be less serious.

18 Priest (1996). 
- A second problem is that victims may be counting on government compensation, which may exactly create an incentive not to purchase insurance. ${ }^{19}$ The problem of government-provided compensation is indeed that it may dilute incentives to purchase insurance since victims could simply free ride on the State. ${ }^{20}$ In the words of Gollier: "Solidarity kills market insurance". ${ }^{21}$ This problem of underinsurance against losses resulting from the generosity of the public at large has been studied by Coate $^{22}$ and has been named the "charity hazard" by Raschky and WeckHannemann. $^{23}$

- A related problem is that there may be negative distributional effects since some victims (who probably purchased houses at low prices in flood prone areas) may free ride on other individuals (the general tax payers) who finance the ex post relief.

A positive aspect of government intervention is, however, that the prospect of largescale pay-outs in the aftermath of a disaster might encourage the government to take cost-benefit justified precautions long before disasters strike. ${ }^{24}$ But even if governments were to take some preventive measures, ex post relief still dilutes incentives to take prevention of other parties involved (more particularly potential victims). Moreover, it is not always clear as to whether or not the government is better at taking preventive measures than potential victims. ${ }^{25}$ All in all, notwithstanding the many arguments against ex post relief, governments in many legal systems can in practice not resist the temptation to provide generous amounts of ( $a d$ hoc or structural) relief after disasters have happened. ${ }^{26}$ As a result, in many countries the compensation for victims of catastrophes is a topic of discussion and legal reform. ${ }^{27}$ One of the issues addressed in that respect is whether it is possible to have a role for the government that is less distortive and provides better incentives for prevention.

\section{Reinsurance by the government}

\section{Principles}

The increasing dissatisfaction with outright ex post relief combined with the feeling that catastrophic losses may be of such a scope that traditional insurance markets

${ }^{19}$ Levmore and Logue (2003, p. 281) and Kaplow (1991).

${ }^{20}$ Gron and Sykes (2002) and Endres et al. (2003, p. 290).

${ }^{21}$ Gollier (2005, p. 25).

22 Coate (1995).

${ }^{23}$ However, Raschky and Weck-Hannemann (2007, p. 328) indicate that the few empirical studies that have studied this phenomenon did not find evidence for charity hazard.

${ }^{24}$ See Levmore and Logue (2003, p. 310).

${ }^{25}$ The argument could for example be made that in the case of terrorism the case for ex post relief is stronger than in the case of natural disasters. The goal of terrorist attacks is often to disrupt society. Providing ex post relief may help to restore public trust. Moreover, terrorists may have adaptive strategies to which governments can potentially better react than individuals. That is different with natural disasters where also civilians could still take some preventive actions. Ex post relief may therefore be more disruptive for incentives to prevent in case of natural disasters than in case of terrorism.

${ }^{26}$ For example in Italy, the government spends on average $€ 3.5$ billion- 4 billion on a yearly basis to identify damages caused by catastrophic events (see Monti and Chiaves, 2006, pp. 167-171).

${ }^{27}$ See the contributions in Faure and Hartlief (2006). 
alone may not be able to provide full coverage led to the development of structures whereby, on the one hand, insurance markets would be used to the extent possible and, on the other hand, the government would merely intervene to support insurance markets where their capacity would fail.

It is these kinds of structures that are now increasingly welcomed by law and economics scholarship. Some have analysed this type of government intervention within the framework of terrorism insurance as "private- and public-insurance responses" 28 ; others have more generally examined "public-private partnerships" consisting of various layers to provide insurance against natural disasters. ${ }^{29} \mathrm{We}$ broadly analyse at this point those cases where government intervention is geared towards supporting the failure of traditional insurance markets, given their inability to supply full coverage in case of disasters of a large scale. It is well known that insurers fear catastrophic losses not only because of the potential magnitude of the damage of a given catastrophe, but also because of the "difficult to predict" nature of a catastrophe. ${ }^{30}$ The basic idea is that, given these problems of insurance markets with supplying catastrophe insurance, a government can play a positive role by, on the one hand, stimulating insurance markets (and thus applying differentiated premiums) and, on the other hand, keeping disaster insurance affordable. ${ }^{31}$ However, even though there seems to be at first blush strong arguments in favour of this type of government intervention, the literature on the topic is quite divided.

\section{Arguments against}

Strikingly, both in law and economics and in legal scholarship, criticisms have been formulated on the facilitative role of a government-stimulating insurance market. For example, Gron and Sykes argue in several papers that it would be unjust for the government to provide (re)insurance at a lower price than the market price. $^{32}$ This would cause price distortion and give a wrong signal to the market as far as stimulating insurability is concerned. The authors would prefer ad hoc solutions whereby compensation is provided to accident victims on an ex post basis. This would avoid the situation that market participants are aware that the government will anyway guarantee compensation.

Also Dutch lawyers Ammerlaan and van Boom, have been critical of an intervention by the (Dutch) government to participate in reinsurance against terrorism. ${ }^{33}$ They argue that the premium that will be demanded is not a correct premium. Moreover, they state that it should not be the task of the State to provide private (re)insurance. Damage caused as a result of terrorism, so they hold, should be financed through the public purse.

\footnotetext{
${ }^{28}$ Levmore and Logue (2003, p. 278).

${ }^{29}$ Kunreuther and Pauly (2006, pp. 112-113).

${ }^{30}$ See Gollier (2005) and Kunreuther (1996, pp. 178-180).

${ }^{31}$ See Kunreuther (2008).

${ }^{32}$ See Gron and Sykes (2002) and Gron and Sykes (2003).

${ }^{33}$ Ammerlaan and van Boom (2003).
} 
It is striking that most of this criticism is not addressed against the intervention of the government as such, but is based on the assumption that the government will not ask premiums that reflect market prices. It is a criticism shared by Levmore and Logue, who argue that such a regime (of acting as reinsurer of last resort) only has its desired effect of encouraging the purchase of commercially provided terrorism coverage when it involves a substantial subsidy. ${ }^{34}$ They are sceptical of these types of interventions in the market (for terrorism insurance) arguing that, also without government intervention, "the market would likely have been able to provide the necessary coverage". ${ }^{35}$ These points can of course only be validated on the basis of empirical research.

Another potential problem with State-backed systems of insurance is that they are inevitably subject to political interest. This could hence lead to the situation that the government would have to intervene as a result of lobbying, also in cases not provided for by the statute of the systems.

\section{Arguments in favour}

The arguments in favour are not surprisingly the mirror image of the arguments against: assuming that capacity on the private insurance market is indeed severely falling behind, it can be assumed that, without State intervention, insurance coverage for disasters would simply not have developed. ${ }^{36}$ Reinsurance by the State can then be considered as an adequate method to resolve the uninsurability problem. A condition is of course that the government charges an actuarially fair premium for its intervention. ${ }^{37}$ This type of government intervention has, moreover, the advantage that ex post relief sponsored through the public purse can be avoided. Where the government acts as reinsurer, this at least has the advantage that a premium can be paid by those who actually cause or run the risk. It can thus facilitate market solutions, still provide incentives for prevention to potential victims and avoid a negative redistribution. Thus a State intervention as reinsurer may avoid the "catastrophic responses to catastrophic risks". 38

Recently, Kunreuther and Michel-Kerjan also argued in favour of governmentprovided reinsurance. They argue that one advantage is that the government has the capacity to diversify the risks over the entire population and to spread past losses to future generations, thus creating a form of cross-time diversification which the private market cannot achieve. ${ }^{39}$ In addition, they argue that, especially as far as terrorism is concerned, government participation in insurance programmes is crucial since the risk

${ }^{34}$ Levmore and Logue (2003, p. 304) (arguing that otherwise disaster insurance would still not be "available").

${ }^{35}$ Levmore and Logue (2003, p. 311).

${ }^{36}$ This is a point strongly made by Kunreuther (1996, pp. 180-183), Harrington (2000) as well as by Schwarze and Wagner (2004).

${ }^{37}$ Faure (2007, p. 358).

${ }^{38}$ Epstein (1996). See in this respect also Kunreuther and Pauly (2006, p. 113) (arguing that this government's role in assisting the supply side allows avoiding the inefficiencies and inequities associated with disaster assistance).

${ }^{39}$ See Kunreuther and Michel-Kerjan (2004, p. 210). 
of terrorist attacks is partly in the government's control and the government can have more information on ongoing terrorist groups' activities through intelligence services. $^{40}$

\section{Practice}

Notwithstanding the objections of some scholars, one can notice the increasing popularity of public-private partnerships in providing disaster insurance, often taking the form of government-provided reinsurance or the government providing an additional layer of compensation. These types of constructions already existed in the nuclear liability conventions which emerged in the 1960s and have gained increasing popularity after 11 September 2001 in guaranteeing insurability of the terrorism risk. ${ }^{41}$ France moreover has a government which intervenes in providing coverage for (mandatorily insured) natural disasters through the Caisse Centrale de Réassurance (CCR). The CCR provides reinsurance via the State and even provides for unlimited coverage (in reinsurance) for natural disasters and technological risks. ${ }^{42}$ Private-public partnerships have also become popular in the U.S. whereby (federal or State) governments act as reinsurers of last resort or as primary insurers. For example, the CEA assumes primary risk-bearing responsibility for the earthquake risk. The private insurer plays an exclusively administrative role, and the risk is taken over by the CEA. A similar model has been developed within the National Flood Insurance Programme (NFIP). ${ }^{43}$ These models seem to enjoy some support in the U.S., because it has been argued that the government only temporarily intervenes to fill a gap that was created in private insurance coverage. Even though this role of the government in providing insurance coverage is still criticised by free market proponents, it undoubtedly has the advantage that it leaves more space for the private market place, especially when compared to ex post government relief. ${ }^{44} \mathrm{We}$ will critically analyse some of these constructions in more detail in section "Some examples of government intervention to examine whether they meet the ideal conditions".

\section{Towards efficient reinsurance by the government?}

The literature we just discussed in the previous section, arguing in favour and against a role for the government as reinsurer for catastrophic risks, implicitly formulates a variety of conditions for this reinsurance to be efficient. In this section, we will hence use the law and economics literature discussed in the previous section to examine

\footnotetext{
${ }^{40}$ Kunreuther and Michel-Kerjan (2005).

${ }^{41}$ For an overview see the contributions in Koch (2004).

${ }^{42}$ For further information on this CCR see http://www.CCR.fr.

${ }^{43}$ Note that the CEA and the NFIP constitute examples of the government as primary insurer, not of the government assuming an additional risk layer. We mentioned in the introduction that our focus is on the role of the government as reinsurer of last resort, but many of the arguments presented here (in favour and against a governmental role) apply obviously to the role of the government as primary insurer as well.

${ }^{44}$ Levmore and Logue (2003, p. 303).
} 
under what particular conditions this type of government intervention could be welcomed. With this literature, we more particularly refer to the economic analysis of accident law as inter alia developed by Shavell, ${ }^{45}$ which is generally based on the idea that a financing or liability system should be structured in such a way that it provides market parties with incentives for prevention. Our conditions are also based on insurance economic literature ${ }^{46}$ with respect to insurance of disasters, stressing that charging risk-related premiums will be welfare increasing.

\section{Absence of market solutions}

An assumption underlying the intervention of the government is that without such an intervention, catastrophe insurance would not be provided to the full extent. Indeed, the whole idea underlying this type of government intervention is that insurance markets for catastrophic risks would in the absence of government intervention not sufficiently develop. If that were not the case, government intervention would merely be distortive and disrupt the normal functioning of the market. The basic reason for government intervention is therefore market failure. Of course, the nature of this failure may also affect the effectiveness of the government solution.

Whether or not without government intervention markets would be able to develop is of course hard to judge and is largely an empirical question. For example, as far as terrorism is concerned, one could of course argue that there is overwhelming empirical evidence that after $9 / 11$ insurance companies all cancelled terrorism coverage. However, that does not necessarily mean that without government intervention the development of a market solution would have been impossible. The danger is always there that insurers may overstate the uninsurability argument since a government taking over a part of the risk may of course well suit their interests. ${ }^{47}$ It may be possible that even without State intervention, private reinsurance for catastrophic risks would develop as well ${ }^{48}$ or that the intervention of the government may be counterproductive in the sense that it dilutes the incentives to develop market insurance. $^{49}$

\section{Charge risk-based premiums}

All law and economics scholars stress that insurance rates should reflect the risk as much as possible. This will have the advantage that it provides a signal to individuals as to the risks they actually face. A system of risk-based premiums will provide incentives to invest in cost-effective loss prevention measures. ${ }^{50}$ State-provided (re)insurance should thus use risk-based premiums which reflect the actual risk as

\footnotetext{
45 Shavell (1987).

46 Priest (1996).

${ }^{47}$ Levmore and Logue (2003, p. 298).

48 Ibid.

${ }^{49}$ Gron and Sykes (2002).

${ }^{50}$ Kunreuther and Pauly (2006, p. 111).
} 
well. ${ }^{51}$ In addition, government reinsurance should not be provided gratis, ${ }^{52}$ since free of charge government-provided reinsurance would amount to a subsidy. ${ }^{53}$

A conclusion from this literature is hence clearly that, to the extent possible, the government should charge a price for the reinsurance service it provides. This of course assumes that the government has information or at least tries to calculate what a reasonable market price would have been for such reinsurance services, if commercial reinsurance were available. The government should hence assess (like in ordinary reinsurance contracts) what the probability would be that it has to provide its additional coverage and on the basis of this assessment and screening (also of the particular risk involved) differentiated premiums have to be charged. In this way, government intervention can still provide appropriate incentives for prevention; otherwise, government intervention would amount to a subsidy which would have the same distortive effect as the ex post government relief discussed above. ${ }^{54}$

Of course, the extent to which the government is able to charge risk-based premiums may to a large extent be related to the nature of the market failure which justifies government intervention. If for example the reason for market failure is a lack of information on the risk, the requirement of charging risk-based premiums is realistic only in case that the government would have better information on the risk than private market players. If the government is uninformed as well, this may clearly also affect the possibility for governments to calculate and charge a fair premium.

\section{Stimulate market solutions}

Reinsurance by the government should preferably be organised in such a way that market solutions are still stimulated. If in reality government intervention were to be too "easy", in the sense that it, for example, comes at too low costs, government reinsurance would provide no incentives to the market to develop its own solutions. One should, however, be slightly careful with this recommendation: there is some empirical evidence from Switzerland presented by Von Ungern-Sternberg, ${ }^{55}$ Emons ${ }^{56}$ and Kirchgässner ${ }^{57}$ that cantonal monopolies for catastrophe insurance proved to be more efficient than market insurance (after liberalisation). This, however, concerned the case where the government acted as primary insurer and had particular advantages because of lower costs of risk differentiation than commercial insurers competing on the market. The Swiss cantonal system of risk transfer is in many respects extraordinary. The efficiency of this system is largely driven by the integration of insurance and risk management tasks in the one hand of the regional insurance monopoly (thus using economies of scale). A recent research showed that the Swiss

\footnotetext{
51 Ibid.

${ }^{52}$ Kunreuther and Michel-Kerjan (2004, pp. 204 and 211).

${ }^{53}$ Levmore and Logue (2003, p. 304).

${ }^{54}$ See also Sugarman (2007).

${ }^{55}$ Von Ungern-Sternberg (2007).

${ }^{56}$ Emons (2001).

${ }^{57}$ Kirchgässner (2007).
} 
public insurance monopoly involved lower transaction costs and was also quite effective in the handling of claims. ${ }^{58}$

\section{Leave freedom with insurers to choose State reinsurance}

An important aspect of stimulating rather than distorting the market would be that a government intervening as a reinsurer of last resort should still leave the freedom with the individual insurer to use the possibility of this State reinsurance or not. Combined with the fact that the State should charge a reinsurance premium which mimics the market, this freedom would still provide possibilities for insurers to look for cheaper alternatives. A requirement to use State-provided reinsurance could clearly endanger competition on the insurance markets.

\section{Temporary character}

For the same reason, government intervention should in principle also have a temporary character (i.e. there should be so-called "sunset provisions"), assuming that the inability of the ordinary reinsurance market is caused by particular exceptional circumstances (such as the uncertainties that arose after 9/11). Moreover, the temporary character of reinsurance by the government can again provide incentives to the market to develop its own solutions.

\section{Some examples of government intervention to examine whether they meet the ideal conditions}

We already mentioned that we are mostly interested in models whereby the government acts as a reinsurer of last resort or provides an additional risk layer. These were the type of arrangements that were referred to in the literature as public-private partnerships. We will now examine a few of the specific arrangements that belong to that model and confront them with the conditions for efficient government intervention in stimulating insurability of catastrophic risks as sketched in the section "Towards efficient reinsurance of the government?". After discussing three cases where the government acts as a reinsurer of last resort, we also provide one example (of the CEA) where the government acts as a primary insurer, simply to show that in that particular case, the market distortive effects are of course potentially still larger.

\section{The French $C C R$ - the government as a reinsurer of last resort}

\section{Description}

France installed a publicly owned reinsurance company to cover natural disasters, the Caisse Centrale de Réassurance or "CCR". 59 Reinsurance is not compulsory, and

\footnotetext{
58 See Raschky et al. (2008).

59 Decree No. 82-706 of 10 August 1982 on the Reinsurance Operations for the Natural Catastrophe Risks by the Caisse Centrale de Réassurance. Application of Article 4 of the Act No. 82-600 of 13 July 1982, JORF 11 August 1982.
} 
insurers are free to contract with other, private, reinsurance companies. Reinsurance with the State reinsurance company is, however, particularly attractive, both because of the reinsurance premiums it charges and because it can offer unlimited cover since it can benefit from a State guarantee in the event that the CCR exhausts its resources. However, a CCR official noted that insurance companies must transfer half of their (natural) catastrophe risk to the CCR in order to be covered under the State guarantee. ${ }^{60}$ The State thus intervenes as a reinsurer, or, more correctly, as a retrocessionaire of the CCR. In fact, in exchange for this State guarantee, the CCR pays a premium to the State (Article R. 431-16-2 Insurance Code), exactly as it should have done if it was protecting itself through an ordinary reinsurer, although evidently the latter could not have delivered him an unlimited guarantee. ${ }^{61}$ The reinsurance programme is set up so that insurers manage policy-holders' claims because they have the best claims-paying experience and expertise. Coverage from the CCR takes effect after insureds pay a certain deductible. ${ }^{62}$

In the first 20 years of its existence, the CCR never managed to accumulate any substantial level of reserves, despite the fact that the average claims/premium ratio of disaster insurance since its creation was only 60 per cent. Disaster insurance was obviously very lucrative for the French private insurers. ${ }^{63}$ Nevertheless, only very few changes to the reinsurance scheme were made, although the CCR reinsured mainly the bad risks and excessively high compensation (24 per cent) was paid for (largely imaginary) administrative costs. ${ }^{64}$ In addition, the combined effects of changes in the market (mergers, freedom of services within Europe, etc.) and the deterioration of the claims figures made it increasingly unsuitable for just a single scheme to be offered. As a result, from 1 January 1997 onwards, the CCR introduced new reinsurance conditions which paid greater attention to the nature of each ceding company's portfolio and forced insurers with a majority of bad risks to retain a larger proportion of the risks. ${ }^{65}$ Still, the CCR was in 1999 on the verge of bankruptcy after it was called upon to make a major withdrawal on its reserves. The French government had to inject three billion French francs (i.e. 457 million EUR) into the CCR to enable it to honour its commitments. Indeed, although no exceptionally large event occurred in 1999, two major events hit France: the flooding in the Aude department in the south

${ }^{60}$ GAO (2005, p. 33).

61 Bidan (2001).

${ }^{62}$ CCR's coverage for natural disasters is unlimited because of the State guarantee. The deductible under the CCR reinsurance contract, therefore, represents the maximum amount that an insurer will have to bear in the course of a year, regardless of how many losses occur.

${ }^{63}$ See: von Ungern-Sternberg (2007, pp. 86-95). Since the insurers have the right, but not an obligation, to reinsure a share of their natural disaster risk with the CCR, they have a strong incentive to lobby the government to set high premiums for natural disasters. It is then in the insurers' interest to reinsure only a small part of their risks and keep the rest of the premiums for themselves.

${ }^{64}$ The effective cost of disaster insurance for the private insurers were, of course, almost nil, since disaster insurance was simply added to already existing property insurance contracts. This also explains why Spanish insurers, through the Consorcio de Compensación de Seguros (which is having an identical system of premium collection), are perfectly happy with just a 5 per cent commission for administrative costs.

${ }^{65}$ CCR (2008). 
during November 1999 (insured losses of 240 million EUR) and a flooding following the winter storms Lothar and Martin (insured losses of 240 million EUR). A significant hurricane also occurred in the French Antilles the same year. At the same time, an unexpected peril new to the industry and to the scheme which appeared in 1989-namely subsidence - had induced the erosion of CCR's reserves over time. As a result, other amendments to the reinsurance scheme needed to be made with the aim of better adapting to the market situation and loss record by, for example, modifying the underwriting conditions, changing the applied deductibles, changing the deductibles in case the municipality does not have a Risk Prevention Plan, recapitalising its reserves, abolishing compensation for administrative costs, etc. ${ }^{66}$

Von Ungern-Sternberg, among others, hereby concludes that these various amendments to the CCR scheme are the outcomes of flaws in the institutional setup. ${ }^{67}$ Cannarsa and others, backed up by the Insurance Journal and A.M. Best on the other hand, attribute a very positive outlook to the CCR ${ }^{68}$ A.M. Best, for example, believes that, despite the high volatility of the guaranteed lines, the impact of a catastrophic event on the company's earnings can be absorbed by CCR's equalisation reserve and, should this be insufficient, by the unlimited state guarantee. ${ }^{69}$

\section{Analysis}

It is not so clear that, without the CCR, insurance of natural disasters would have been impossible. Of course, one should understand the creation of the CCR in combination with the mandatory coverage for damage caused by natural disasters in France, mentioned above. ${ }^{70}$ It is clear though, that an unlimited guarantee (which is provided by the French State to the CCR) would of course never be provided by an ordinary reinsurer. The CCR has to pay a premium for the State guarantee provided which should in principle be market based. Hence, it is also not clear how the creation of the CCR would stimulate the emergence of a market solution, nor does it have a temporary character. Insurers would have freedom to contract with other, private, reinsurance companies, but some sources argue that insurance companies would have to transfer at least half of their natural disaster risk to the CCR. In fact, the CCR is clearly not market competitive, since the premiums would be particularly attractive (compared to commercial reinsurers) and because of the unlimited State guarantee. In that sense, the system is more disruptive of the market than that it stimulates market solutions. The CCR also suffers from the influence of political interest mentioned above. The case of subsidence (which is a problem mainly in the south of France) demonstrates this point. It was a risk not originally envisaged in the setup of the CCR, but still declared a national catastrophe ex post by the French State. This shows that State-backed insurance schemes can get out of contractual hands by lobby interests.

\footnotetext{
${ }^{66}$ See the following contributions on the CCR: Jametti and von Ungern-Sternberg (2004); Jametti and von Ungern-Sternberg (2006); Vallet (2005).

${ }^{67}$ von Ungern-Sternberg (2007, pp. 82-104).

${ }^{68}$ See Moréteau et al. (2006, p. 102).

${ }^{69}$ Press Release, A.M. Best, 19 June 2009.

${ }^{70}$ See section "Mandatory comprehensive insurance".
} 


\section{TRIA-the government as a reinsurer of last resort}

\section{Description}

The American Terrorism Risk Insurance Act of 2002 ("TRIA") establishes a temporary programme of shared public and private compensation for insured losses resulting from foreign acts of terrorism in order to "protect consumers by addressing market disruptions and ensure the continued widespread availability and affordability" of terrorism insurance, and to "allow for a transitional period for the private markets to stabilize, resume pricing of such insurance, and build capacity to absorb any future losses (...)". ${ }^{71}$ TRIA creates a federal backstop for terrorism insurance, meaning that federal financial support is provided for payment of terrorism claims in the event of a fairly large terrorism incident. The programme is similar to reinsurance in that it provides reimbursement to insurers after they pay claims to a specified level (the deductible) and in that insurers retain a portion of the risk (a co-pay). ${ }^{72}$ However, a difference with reinsurance is that insurers do not pay a premium to be eligible and the government does not establish any reserves. Instead, the costs of the TRIA programme are born by the taxpayers with some or all of the costs subject to recoupment. In short, the TRIA offers an illustration of the federal government providing coverage above a baseline risk that remains under the coverage of private insurers. The federal government temporarily assumes the role of excess liability insurer (i.e. reinsurer of last resort), providing a cap on the losses for which the private insurance industry remains responsible in the event of a terrorist attack. ${ }^{73}$ The programme would initially exist for two years, with the expiration date set at 31 December 2005, but has been systematically extended ever since.

All insurers providing commercial ${ }^{74}$ property or casualty insurance are required to participate in the programme as elaborated in the TRIA. The insurers must make terrorism insurance available to all policy-holders, but are free to choose the applicable extra terrorism premium, which should not be excessive, inadequate or fairly discriminatory.

If a certified foreign act of terrorism causes losses in excess of US\$5 million (since 2005: US\$100 million), participating insurers must pay a certain amount in claims - a deductible - before federal governmental assistance can become available. During the so-called transition period (from 26 November 2002 to 31 December 2002), this

${ }^{71}$ The TRIA act does not cover any of the September 11 losses.

${ }^{72}$ Russell and Thomas (2008).

${ }^{73}$ Rabin and Bratis (2006, p. 325).

${ }^{74}$ TRIA only applies to commercial property and casualty insurance, which is defined to specifically include excess insurance, workers' compensation insurance, and during the first three years of the TRIA Program, surety insurance. (Workers' compensation insurance mandatorily includes insurance against terrorism, even without TRIA. See Hockman et al. (2004) for how workers' compensation can deal with the problem of terrorism losses.) TRIA does not apply to personal insurance, such as homeowners', automobile or life insurance. Moreover, by law, the TRIA programme does not apply to: federal or private crop insurance; private mortgage insurance, or title insurance; financial guaranty insurance offered by a monoline financial guaranty insurance corporation; insurance for medical malpractice; health or life insurance, including group life insurance; federal flood insurance; and reinsurance or retrocessional reinsurance. 
deductible was 1 per cent of the value of the insurer's directly earned premiums during the year preceding the Act's enactment. During 2003, the deductible was 7 per cent of the insurer's directly earned premiums for the preceding year, and it rose to 10 per cent during 2004. In 2005 (when the programme was extended), the deductible was 15 per cent of the insurer's directly earned premiums during the preceding year, and raised to 17.5 per cent of the direct earned premium in 2005 extension, and then to 20 per cent in 2007. Losses above the deductible will for 90 per cent (since 2005: 85 per cent) be covered by the federal government, while the insurance industry contributes 10 per cent (now: 15 per cent). An annual cap of US\$100 billion to all aggregate insured losses has been installed. In case the cap would be exceeded, Congress has the authority to decide who will pay and in what amounts: the Secretary shall determine the pro rata share of insured losses to be paid by each insurer that incurs insured losses under the programme. Insurers that meet the deductible will not be liable for losses in excess of this cap.

\section{Analysis}

TRIA was clearly created because, after 9/11, insurance companies had withdrawn worldwide from covering the terrorism risk and hence at that moment one could argue that there was effectively an absence of a market solution (whereby it still is another issue whether insurers were right in massively cancelling all coverage for the terrorism risk). However, it is clear that the reinsurance provided by TRIA is an outright subsidy since insurers do not pay a premium for the State intervention provided. An important feature of TRIA is that the State does not completely take over the risk since a particular (modest) deductible applies which has also been raised. Even though the deductibles are still modest, one could argue that this has the character of still stimulating a market solution. Formally, TRIA was a temporary programme, but it has meanwhile always been extended.

\section{The Dutch Agriver-the government as reinsurer of last resort}

\section{Description}

Agricultural damage in the agrarian sector caused by heavy rainfall in the Netherlands is since 2002 covered through an insurance pool, as agreed between the government and the Dutch Association of Insurers. Crop insurance compensates damage to crops caused by heavy rainfall. The pool will pay out damages up to an amount of 50 million EUR and the State intervenes between 50 and 100 million EUR with a total insured value of 3.5 billion EUR. On 15 October 2003 the subsidy provided by the central government (in the form of a guarantee) was approved by the European Commission. As a result two pools were instituted, called Agriver and OWM AquaPol, which both applied for the subsidy in the form of a guarantee by the central government. On 18 March 2004 the government signed the guarantee agreement with Agriver and OWM AquaPol. ${ }^{75}$ Damage caused by frost, drought or snow was not covered, although it

\footnotetext{
${ }^{75}$ OWM AquaPol has decided to cease its insurance activities from 2009 onwards, because of the limited number of insured parties.
} 
could count on great interest from the crop farmers. As a result, in 2007, crop insurance was expanded to include compensation of damage to crops in the fruit farming sector caused by extreme frost. The European Commission approved this extension of the regulation on 19 June 2007. The Dutch State hereby provides a subsidy in the form of a guarantee as a stimulus for insurance companies from 6,677.400 EUR to a maximum of 20,927.400 EUR per year for frost damage with a total insured value of 762.6 million EUR. Since 1 November 2007, the Onderlinge Fruittelers Hagelverzekeringsmaatschappij ("OFH") offers frost insurance for the fruit growers. Further, the decision of the European Commission altered the State aid rules regarding the first branch of crop insurance. Since then, the State intervenes between 46.5 and 96.5 million EUR per year with a total insured value of 3,255 billion EUR. In both cases, a deductible of 25 per cent per crop applies. However, from the cultivation season of 2006 onwards, growers who are insured through AquaPol can choose for a deductible of 15 or 25 per cent. In return for the governmental intervention, the insurance companies are obliged to pay a premium of 0.1 per cent of the total insured value to the State. The insurers are moreover obliged to channel the total advantage of the guarantee to the insured (the farmers) via an increase in the insurance premium. This body of insurance contracts is now called "new agrarian indemnity insurance". Of course, various private insurance companies offer hail insurance or storm insurance, but reinsurance takes place without governmental support.

\section{Analysis}

The intervention of the Dutch government in Agriver (by providing a guarantee in case of large losses) seemed necessary for the simple reason that in the Netherlands, damage caused by heavy rainfall and flooding had been excluded as a result of a cartel agreement between insurers which dates from the 1950s. Even though this cartel was lifted after European pressure, the Dutch insurers continued to refuse to cover damage caused by flooding and heavy rainfall. There was hence indeed no market solution, but one should note that this was rather the result of anti-competitive behaviour by the Dutch insurers than of genuine insurance technical problems with the supply of disaster insurance. It can hence be doubted whether a government intervention in this case was indeed needed. The insurance companies are obliged to pay a premium for the government intervention provided. However, this is a percentage of the total insured value and is not linked at all to the risk posed. The system therefore does not provide incentives to develop a market solution, nor does it have a temporary character.

\section{The CEA-the government as a primary insurer}

\section{Description}

The CEA provides an example of a government stepping into the private insurance market and assuming the risk of a potential natural catastrophe. In short, the CEA is a publicly managed, privately funded organisation (without government backing) that was established in September 1996, after the Northridge earthquake in 1994, by the State of California to sell California residential earthquake insurance policies through 
participating insurance companies and to encourage Californians to reduce their risk of earthquake loss.

The State of California requires insurers doing business in the State to offer also earthquake coverage in their homeowners' policies, either directly or through a separately State-sponsored earthquake fund, the CEA. As already said before, the CEA is empowered to set premiums and to bear risks, but a so-called "mini-policy" lays down which classes of real estate losses are covered and which not. In addition, the premiums must be set on an actuarial basis, but, in practice, the quoted CEA premiums have been tempered so that the price differences between the regions are moderated. Also, the CEA may purchase reinsurance, but it does not have access to public funds. As a result, CEA resources are only adequate to compensate an event which is double the size of the Northridge Earthquake, but beyond that level, policy-holders will only receive partial compensation.

Participation in the CEA is voluntary, so that private insurance companies may and do compete with the CEA, although this competition is mainly limited to the low-risk locations. It seems that the CEA charges considerable premiums and many homeowners find these too high relative to the coverage provided. Consequently, the percentage of Californians with earthquake coverage (through CEA or a private insurer) declined from 33 per cent in 1996 to 13 per cent in $2007 .^{76}$ In 2004, the Authority had a claims-paying ability of US\$6.9 billion and wrote 47.3 per cent of earthquake premiums. The CEA is criticised for its high deductibles (15 per cent of the loss) and low compensation amounts.

\section{Analysis}

Confronting the features of the CEA with the conditions sketched above, it is doubtful whether there really was an absence of a market solution after the Northridge Earthquake, since other insurers than the CEA also provided coverage for earthquakes. It is an example where the government in fact steps in as a primary insurer and thus competes with other insurers. Premiums would reflect risk, but it is not clear how the CEA stimulates a market solution since the government in fact competes with commercial insurers doing the same. The CEA does not seem to have a temporary character and the freedom to join the CEA is relative since insurers are required to offer earthquake coverage either themselves or through the CEA.

\section{Summary}

We presented four differing cases where the government provides some kind of intervention, usually to supplement insurance coverage in the compensation of disasters. These examples and the subsequent analysis could easily be extended to other cases as well. All we wish to show with these examples is that, in fact, no matter what type of structure is followed, there are some striking differences and similarities.

\footnotetext{
${ }^{76}$ Residential and Commercial Earthquake Insurance Coverage Study 2007, California Department of Insurance, available at: www.insurance.ca.gov/0400-news/0200-studies-reports/0300-earthquake-study/upload/EQ2007_Summary_Final_Exposure_May0508.pdf.
} 
Table 1 Comparison of four cases

\begin{tabular}{lccccc}
\hline & $\begin{array}{c}\text { Absence of } \\
\text { market } \\
\text { solution? }\end{array}$ & $\begin{array}{c}\text { Premiums } \\
\text { reflect } \\
\text { risk? }\end{array}$ & $\begin{array}{c}\text { Stimulate } \\
\text { market } \\
\text { solution? }\end{array}$ & $\begin{array}{c}\text { Freedom for } \\
\text { insurer to } \\
\text { choose? }\end{array}$ & $\begin{array}{c}\text { Temporary } \\
\text { character? }\end{array}$ \\
\hline CCR & $+/-$ & $+/-$ & - & $+/-$ & - \\
TRIA & + & - & $+/-$ & - & $+/-$ \\
Agriver & $+/-$ & $+/-$ & - & $+/-$ & - \\
CEA & - & + & - & - \\
\hline
\end{tabular}

It is striking that not in all cases, a premium is asked for government intervention (for example not in TRIA) and that in cases where this premium is asked, it is doubtful that the premium actually reflects the risk. Moreover, in some cases, the government in fact competes with the market (CEA) and in other cases merely provides a government guarantee because otherwise an insurance cartel simply refuses to provide coverage altogether (Agriver in the Netherlands). In those cases, government intervention is problematic in the sense that one can wonder to what extent it actually stimulates a market solution. Moreover, none of the solutions presented has a temporary character (although TRIA has been established as a temporary solution). All in all, all examples (which are related to different countries and differing risks) show that, notwithstanding which of the models is followed, it is apparently difficult to structure government intervention in a way that corresponds with economic principles. These (preliminary) results do give some support to those who were critical of government intervention in the first place. ${ }^{77}$

The results from this modest comparison of the four cases can be summarised in Table 1.

\section{Concluding remarks}

Compensation for victims of catastrophes is a hot topic in many countries today and the legislator is increasingly intervening to stimulate the functioning of the catastrophe insurance markets in what is now referred to as "public-private partnerships". ${ }^{78}$ The reactions in the literature to these types of constructions vary quite a bit: some economic literature relying largely on market solutions is quite critical of government intervention, whereas other, more insurance-related, literature argues that these types of government intervention stimulating the supply of insurance coverage should be welcomed since they increase the insurability of risks that would otherwise be

\footnotetext{
${ }^{77}$ Gron and Sykes (2002) as well as Levmore and Logue (2003).

${ }^{78}$ These possible forms of government intervention focus on the supply side. There are, however, a lot of other alternatives which are discussed in the literature as well, some of which for example equally focus on the demand side. One could in that respect think of tax reductions for victims of catastrophes, but also of outright subsidies to charitable organisations (Levmore and Logue, 2003, pp. 308-309). If compensation of victims is the main goal, other structural arrangements could of course be thought of, for example in the sphere of social security (see Sugarman, 2007 and see Van Langendonck, 2007). Discussing these alternatives was of course outside the scope of our paper.
} 
uninsurable. The aim of our paper was to add to that debate by, on the one hand, discussing a few specific cases where this type of government intervention is provided and, on the other hand, confronting these with the law and economics literature.

We sketched on the basis of theoretical law and economics literature that it may be possible to provide a few conditions that would have to be fulfilled to make government intervention to supplement insurance markets for disasters efficient, or at least as little disruptive as possible. To some extent, it may of course be difficult to test these particular conditions. For example, one important question is whether government intervention is absolutely necessary in the sense that, without government intervention, a similar market solution would not have emerged. Also, a condition to make government intervention efficient would be that a premium is asked for this intervention which mimics the market solution. But that supposes that one actually knows what an actuarially fair premium would be, which may in some cases be difficult to calculate. Moreover, as many of the examples we discussed showed, sometimes the government simply does not want to ask an actuarially fair premium for its intervention since this may jeopardise the affordability of the scheme (i.e. premiums may become prohibitively high). However, if that were the case, one could question whether the government should intervene by providing gratis reinsurance or whether specific differentiated subsidies should be provided to individuals to allow them to purchase differentiated insurance contracts. ${ }^{79}$ The examples we examined showed at least that it is apparently difficult in practice to structure government intervention in such a way that it corresponds with economic starting points. To some extent, this may not be surprising since some of this government intervention does not only aim at efficiency but also at redistribution. However, the question then again arises as to whether or not acting as a reinsurer of last resort is the most effective way of redistributing money to victims of catastrophes. We still feel that this intervention may be less distortive than ex post relief. By stimulating or backing up insurance markets, at least some differentiation of risks is possible - which is usually totally absent in the case of ex post relief.

Our paper merely focused on the role of governments in providing compensation for victims of catastrophes. Recently, many countries have also witnessed massive government support for financial institutions. To some extent, the issues we have raised in this paper are similar to the issues raised by the recent bailout of financial institutions. There are undoubtedly similarities, but also striking differences between those cases. An interesting question is how government support to the financial system compares with government support to victims of catastrophes on the basis of the criteria we have developed in section "Towards efficient reinsurance by the government?" of this paper. This may be an interesting extension of the analysis provided in this paper and hence a point for further research.

\section{References}

Ammerlaan, K. and van Boom, W.H. (2003) 'De Nederlandse Herverzekeringsmaatschappij voor Terrorismeschaden en de rol van de overheid bij het vergoeden van terreurschade', Nederlands Juristenblad 45/46: 2330-2339.

${ }^{79}$ As recently suggested by Kunreuther (2008). 
Bidan, P. (2001) 'Le régime d'indemnisation des catastrophes naturelles a-t-il un avenir?' R.G.D.A. 2: $243-252$.

CCR (2008) Les Catastrophes Naturelles en France-Natural Disasters in France, Paris: Caisse Centrale de Réassurance, April.

Coate, S. (1995) 'Altruism, the Samaritan's dilemma and government transfer policy', American Economic Review 85(1): 46-57.

Daniels, R.J., Kettl, D.F. and Kunreuther, H. (2006) On Risk and Disaster: Lessons from Hurricane Katrina, Philadelphia, PA: University of Pennsylvania Press.

Durant, I. (2006) 'Belgium', in M. Faure and T. Hartlief (eds.) Financial Compensation for Victims of Catastrophes Comparative Legal Approach, Vienna: Springer, pp. 37-80.

Emons, W. (2001) 'Imperfect tests and natural insurance monopolies', Journal of Industrial Economics 49(3): $247-268$.

Endres, A., Ohl, C. and Rundshagen, B. (2003) “"Land unter!” Ein institutionenökonomische Zwischenruf”, List Forum für Wirtschafts- und Finanzpolitik 29: 284-294.

Epstein, R.A. (1996) 'Catastrophic responses to catastrophic risks', Journal of Risk and Uncertainty 12(2-3): 287-308.

Faure, M.G. (2007) 'Financial compensation for victims of catastrophes: A law and economics perspective', Law \& Policy 29(3): 339-367.

Faure, M.G. and Bruggeman, V. (2009) 'Catastrophic risks and first-party insurance', Connecticut Insurance Law Journal 15(1): 1-52.

Faure, M.G. and Hartlief, T. (2006) Financial Compensation for Victims of Catastrophes-A Comparative Legal Approach, Vienna: Springer.

Froot, K.A. (1999) The Financing of Catastrophe Risk, Chicago and London: The University of Chicago Press.

GAO (2005) Catastrophe Risk. U.S. and European Approaches to Insure Natural Catastrophe and Terrorism Risks, (February), GAO-05-199, Washington, DC: United States Government Accountability Office.

Gollier, C. (2005) 'Some aspects of the economics of catastrophe risk insurance', in OECD (ed.) Catastrophic Risks and Insurance, Paris: OECD Publishing, pp. 13-30.

Gron, A. and Sykes, A.O. (2002) 'A role for government?' Regulation 25(4): 44-51.

Gron, A. and Sykes, A.O. (2003) 'Terrorism and insurance markets: A role for the government as insurer?' Indiana Law Review 36: 447-463.

Harrington, S.E. (2000) 'Rethinking disaster policy', Regulation 23(1): 40-46.

Hinghofer-Szalkay, D. and Koch, B.A. (2006) 'Austria', in M. Faure and T. Hartlief (eds.) Financial Compensation for Victims of Catastrophes. A Comparative Legal Approach, Vienna: Springer, pp. 7-36.

Hockman, B., Lowe, S., Shah, S. and Wolstein, C. (2004) Workers' Compensation Terrorism Reinsurance Pool Feasibility Study: Summary of Study Findings and Conclusions, New York: Tillinghast and Reinsurance businesses of Towers Perrin.

Jametti, M. and von Ungern-Sternberg, T. (2004) Disaster insurance or a disastrous insurance-Natural disaster insurance in France, CESifo Working Paper Series No. 1303.

Jametti, M. and von Ungern-Sternberg, T. (2006) Risk selection in natural disaster insurance-The case of France, CESifo Working Paper Series No. 1683.

Kaplow, L. (1991) 'Incentives and government relief for risk', Journal of Risk and Uncertainty 4(2): 167-175.

Kirchgässner, G. (2007) 'On the efficiency of a public insurance monopoly: The case of natural hazard insurance in Switzerland', in P. Baake and R. Borck (eds.) Public Economics and Public Choice: Contributions in Honor of Charles B. Blankart, Berlin: Springer, pp. 221-242.

Koch, B.A. (2004) Terrorism, Tort Law and Insurance: A Comparative Survey, Vienna: Springer.

Kunreuther, H. (1968) 'The case for comprehensive disaster insurance', The Journal of Law \& Economics 11(1): 133-163.

Kunreuther, H. (1996) 'Mitigating disaster losses through insurance', Journal of Risk and Uncertainty 12 : 171-187.

Kunreuther, H. (2008) 'Reducing losses from catastrophic risks through long-term insurance and mitigation', Social Research: An International Quarterly of Social Sciences 75: 905-930.

Kunreuther, H. and Michel-Kerjan, E. (2004) 'Challenges for terrorism risk insurance in the United States', Journal of Economic Perspectives 18(4): 201-214. 
Kunreuther, H. and Michel-Kerjan, E. (2005) 'Insurability of (mega-) terrorism risk: Challenges and perspectives', in OECD (ed.) Terrorism Risk Insurance in OECD Countries, Paris: OECD Publishing, pp. $107-148$.

Kunreuther, H. and Pauly, M. (2006) 'Rules rather than discretion: Lessons from hurricane Katrina', Journal of Risk and Uncertainty 33(1): 101-116.

Levmore, S. and Logue, K.D. (2003) 'Insuring against terrorism-And crime', Michigan Law Review 102(2): 268-327.

Magnus, U. (2006) 'Germany', in M. Faure and T. Hartlief (eds.) Financial Compensation for Victims of Catastrophes. A Comparative Legal Approach, Vienna: Springer, pp. 119-144.

Monti, A. and Chiaves, F.A. (2006) 'Italy', in M. Faure and T. Hartlief (eds.) Financial Compensation for Victims of Catastrophes. A Comparative Legal Approach, Vienna: Springer, pp. 145-194.

Moréteau, O. (2007) 'Policing the compensation of victims of catastrophes: Combining solidarity and self-responsibility', in W.H. van Boom and M. Faure (eds.) Shifts in Compensation between Private and Public Systems, Vienna, New York: Springer, pp. 199-218.

Moréteau, O., Cannarsa, M. and Lafay, F. (2006) 'France', in M. Faure and T. Hartlief (eds.) Financial Compensation for Victims of Catastrophes. A Comparative Legal Approach, Vienna: Springer, pp. 81-118.

Priest, G.L. (1996) 'The government, the market, and the problem of catastrophic loss', Journal of Risk and Uncertainty 12(2-3): 219-237.

Rabin, R.L. and Bratis, S.A. (2006) 'United States', in M. Faure and T. Hartlief (eds.) Financial Compensation for Victims of Catastrophes. A Comparative Legal Approach, Vienna: Springer, pp. 303-360.

Raschky, P., Schwarze, R., Schwindt, M. and Weck-Hannemann, H. (2008) Alternative Financing and Insurance Solutions for Natural Hazards. A Comparison of Different Risk Transfer Systems in three Countries-Germany, Austria and Switzerland-affected by the August 2005 Floods, Bern: KGV Prevention Foundation, http://www.alp-s.at./cms.

Raschky, P. and Weck-Hannemann, H. (2007) 'Charity hazard-A real hazard to natural disaster insurance' Environmental Hazards 7: 321-329.

Russell, T. and Thomas, J.E. (2008) Government Support for the Terrorism Insurance Industry: Where Do We Go From Here? Research Symposium on Insurance Markets and Regulation, Searle Center on Law, Regulation, and Economic Growth, Northwestern University.

Schwarze, R. and Wagner, G.G. (2004) 'In the aftermath of Dresden: New directions in German flood insurance', The Geneva Papers on Risk and Insurance - Issues and Practice 29(2): 154-168.

Shavell, S. (1987) Economic Analysis of Accident Law, Cambridge: Harvard University Press.

Slovic, P. (2000) The Perception of Risk, London: Earthscan Publications.

Slovic, P., Fischhoff, B., Lichtenstein, S., Corrigan, B. and Comb, B. (1977) 'Preference for insuring against probably small losses: Insurance implications', The Journal of Risk and Insurance 44(2): 237-258.

Slovic, P., Kunreuther, H. and White, G. (2000) 'Decision processes, rationality and adjustment to natural hazards', in P. Slovic (ed.) The Perception of Risk, London: Earthscan Publications, pp. 1-31.

Sugarman, S.D. (2007) 'Roles of government in compensating disaster victims', Issues in Legal Scholarship 10.

Vallet, S. (2005) 'The French experience in the management and compensation of large scale disasters', in OECD (ed.) Catastrophic Risks and Insurance, Paris: OECD Publishing, pp. 293-301.

Van Langendonck, J. (2007) 'International social insurance for natural disasters?' in W.A. van Boom and M. Faure (eds.) Shifts in Compensation between Private and Public Systems, Vienna: Springer, pp. 187-197.

von Ungern-Sternberg, T. (2007) Efficient Monopolies - The Limits of Competition in the European Property Insurance Market, Oxford: Oxford University Press.

\section{About the Authors}

Véronique Bruggeman studied law at the Catholic University of Leuven (Belgium) and also obtained an LL.M. in Energy and Environmental Law (2004) there. She started to practice as a lawyer in the international law firm DLA Piper Rudnick LLP, and has been working on a Doctoral dissertation on "Financial 
Compensation for Victims after Catastrophes from a Comparative Law and Economics Perspective" at Maastricht University, the Netherlands. She obtained her $\mathrm{PhD}$ in March 2010.

Michael G. Faure obtained an LL.M. degree from the University of Chicago Law School (1985) and a Doctorate from the Albert Ludwigs Universitat Freiburg in Breisgau, (Germany). He is currently Professor of Comparative and International Environmental Law at Maastricht University, the Netherlands, and Academic Director of the Maastricht European Institute for Transnational Legal Research (METRO). He is also Professor of Law and Economics at Erasmus University Rotterdam. He publishes on (the law and economics of) accidents, insurance, and environmental law.

Karine Fiore is Doctor in Economics and currently works at the French Chemicals Agency (Afsset). Her research focuses on the industrial and chemical risks. The analytical tools she relies on are those provided by the literature on industrial economics and institutional economics. In the past, she worked on the sustainability and the energy policy choices and on the economic analysis of decision processes regarding management of nuclear risk. 